\title{
PENGUATAN PENINGKATAN KAPASITAS MASYARAKAT DALAM PENGELOLAAN DESA WISATA BERBASIS PENGURANGAN RESIKO BENCANA DI DESA PUJON KIDUL KABUPATEN MALANG
}

\author{
Linda Dwi Rohmadiani' ${ }^{1)}$, Moch. Shofwan ${ }^{2)}$, Suning ${ }^{3)}$ \\ ${ }^{1,2,3}$ Program Studi Perencanaan Wilayah dan Kota, Fakultas Teknik Sipil dan Perencanaan \\ Universitas PGRI Adi Buana Surabaya \\ Email: ${ }^{1}$ linda@unipasby.ac.id, ${ }^{2}$ shofwan.moch@unipasby.ac.id, ${ }^{3}$ suning@unipasby.ac.id
}

\begin{abstract}
Abstrak
Wilayah Desa Pujonkidul merupakan dataran tinggi dengan kemiringan 25 - 40\% dan termasuk wilayah DAS Konto, sehingga rawan terjadi bencana longsor karena jenis tanahnya berupa aluvial. Berdasarkan data BPBD Tahun 2018, Kecamatan Pujon (termasuk Desa Pujonkidul) termasuk dalam daerah rawan bencana longsor. Tahapan kegiatan pengabdian kepada masyarakat dimulai dengan survei awal, analisis situasi, mendesain kegiatan dan sasarannya, pelaksanaan sosialisasi, evaluasi dan terakhir pelaporan. Kegiatan penguatan kapasitas masyarakat dalam pengurangan risiko bencana diikuti oleh 20 masyarakat desa yang mewakili 3 dusun di Desa Pujonkidul pada Bulan November 2019. Sosialisasi selenggarakan mulai jam 10.00 sampai jam 12.00 WIB membahas mengenai naskah draft peraturan desa tentang penyelenggaraan penanggulan bencana di desa. Hasil kegiatan pengabdian kepada masyarakat adanya perubahan pengetahuan masyarakat dan aparatur desa dalam mengurangi risiko bencana di Desa Pujonkidul.
\end{abstract}

Kata Kunci: Diseminasi, Kapasitas Masyarakat, Pengurangan Risiko Bencana

\begin{abstract}
The Pujonkidul Village area is a plateau with a slope of $25-40 \%$ and is included in the Konto watershed area, so that it is prone to landslides due to alluvial soil types. Based on 2018 BPBD data, Pujon Subdistrict (including Pujonkidul Village) is included in an area prone to landslides. Stages of community service activities begin with a preliminary survey, situation analysis, designing activities and targets, conducting socialization, evaluating and finally reporting. Activities to strengthen community capacity in disaster risk reduction were followed by 20 village communities representing 3 hamlets in Pujonkidul Village in November 2019. The socialization was held from 10.00 to 12.00 WIB. The material presented was about the draft of a village regulation draft on the implementation of disaster management in the village. The results of community service activities are changes in community knowledge and village apparatus in reducing disaster risk in Pujonkidul Village.
\end{abstract}

Keywords: Dissemination, Community Capacity, Disaster Risk Reduction

\section{PENDAHULUAN}

Desa Pujonkidul merupakan wilayah Kecamatan Pujon yang memiliki batas administratif: sebelah Utara berbatasan dengan Desa Ngroto, sebelah Selatan berbatasan dengan Kabupaten Blitar, sebelah Barat berbatasan dengan Desa Sukomulyo dan sebelah Timur berbatasan dengan Desa Pujon Lor (Gambar 1). Jarak tempuh ke ibukota kecamatan sejauh $3 \mathrm{~km}$ dengan lama tempuh sekitar 10 menit. Desa Pujonkidul terbagi menjadi 3 wilayah yaitu Dusun Krajan terdiri atas 11 RT dan 6 RW, Dusun 
Maron terdiri atas 5 RT dan 2 RW dan Dusun Tulungrejo terdiri atas $2 \mathrm{RT} 1 \mathrm{RW}$.

Kemiringan lahan wilayah Kecamatan Pujon sebesar $25-40 \%$ yang dikelilingi oleh 7 gunung, antara lain:

a. Gunung Biru (Wiyurejo)

b. Gunung Argowayang (Tawangsari)

c. Gunung Gentong Growah (Madiredo)

d. Gunung Dworowati (Ngabab)

e. Gunung Kukusan

f. Gunung Parangklakah

g. Gunung Kawi (Pujonkidul)

h. Gunung Cemoro Kandang dan Gunung Anjasmoro (Sebaluh, Coban Rondo).

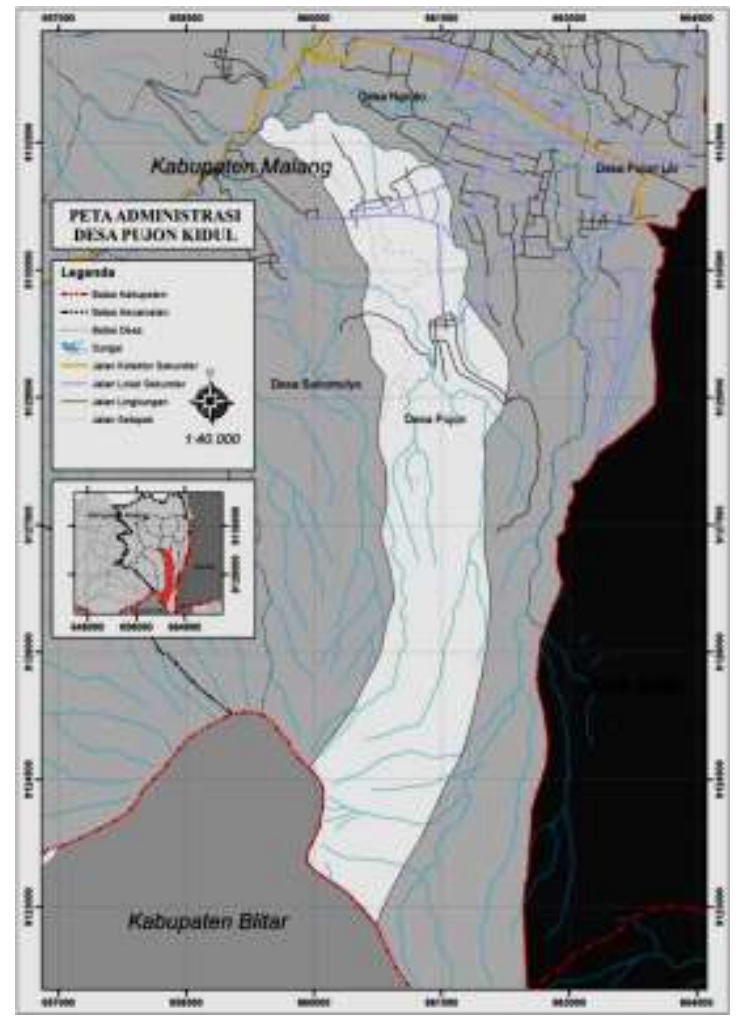

Gambar 1. Peta Administratif Desa Pujonkidul

Jenis penggunaan lahan Desa Pujonkidul pada Tahun 2017 terbagi atas lahan terbangun sebesar $21 \%$ dan lahan tidak terbangun sebesar $79 \%$. Lahan tidak terbangun tersebut berupa ladang $40 \%$ dan sawah $39 \%$. Wilayah desa ini secara umum sangat cocok untuk lahan pertanian dan perkebunan karena berjenis aluvial yang tergolong tanah subur yang cocok yaitu jagung, apel, tomat, dan wortel. Kondisi sosial kependudukan desa pada Tahun 2017 memiliki jumlah penduduk sebesar 4.133 jiwa dengan kepadatan penduduk rendah yaitu $148 \mathrm{jiwa} / \mathrm{km}^{2}$. Jenis mata pencaharian penduduk adalah sektor pertanian.

Potensi wisata yang ada di Desa Pujonkidul berupa wisata alam air terjun Sumber Pitu, agrowisata petik sayur dan buah, racking Gunung Kawi, wisata outbound, Cafe Sawah, Kesenian Sadukan, Kesenian Kuda Luumping, sentra olahan susu dan wisata edukasi ternak sapi (Gambar 2). Jumlah kunjungan wisatawan pada hari biasa sekitar 400-500 orang sedangkan pada akhir pekan mencapai 2.000 sampai 3.000 orang. Amenitas yang tersedia berupa 55 homestay, warung makanan tradisional, pusat informasi, sarana telekomunikasi, air bersih dan listrik (Rachmadana, 2018).

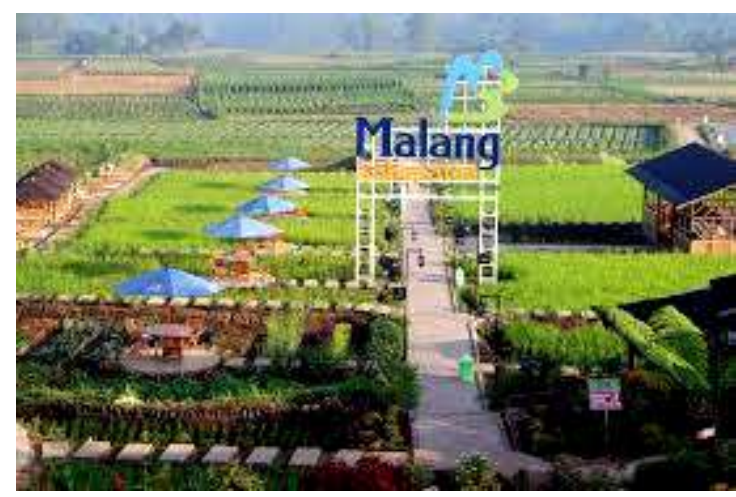

Gambar 2. Potensi Wisata Desa Pujonkidul

Berdasarkan data Badan Penanggulangan Bencana Daerah (BPBD) Kabupaten Malang Tahun 2018, sebanyak 18 kecamatan terdampak bencana tanah longsor salah satunya adalah Kecamatan Pujon, sehingga diperlukan adanya rencana penanggulangan bencana (Ahdi,2015; Lupito, 2019 dan Al Faruq, 2019). UndangUndang No. 24 Tahun 2007 tentang Penanggulangan Bencana, menyebutkan bahwa penyelenggaraan penanggulangan bencana meliputi penetapan kebijakan pembangunan yang berisiko timbulnya bencana, kegiatan pencegahan bencana, tanggap darurat, dan rehabilitasi seperti pada Gambar 3. 


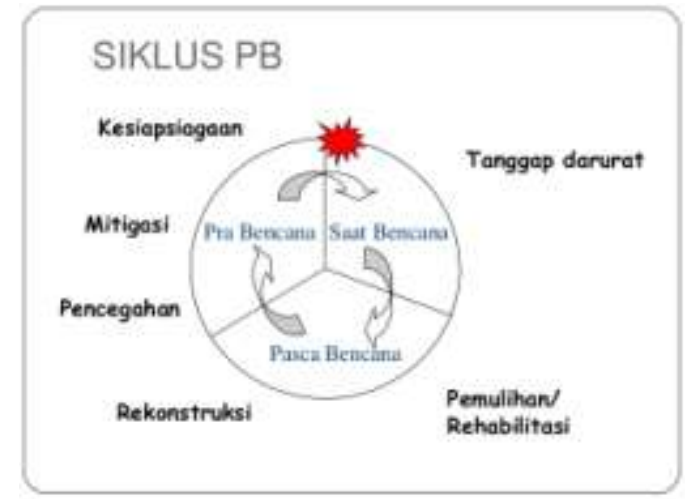

Gambar 3. Tahapan Penanggulangan Bencana
Kemampuan masyarakat untuk melakukan tindakan pengurangan ancaman dan potensi kerugian akibat bencana atau kapasitas masyarakat, terbagi atas kapasitas individu dan dan kapasitas kelembagaan sebagaimana dijelaskan dalam Gambar 4. Kapasitas individu dipengaruhi oleh pengetahuan, kearifan lokal dan rencana aksi. Kapasitas kelembagaan dipengaruhi oleh adanya kepemimpinan dan program, informasi serta fasilitas (Nugraha et al, 2018).

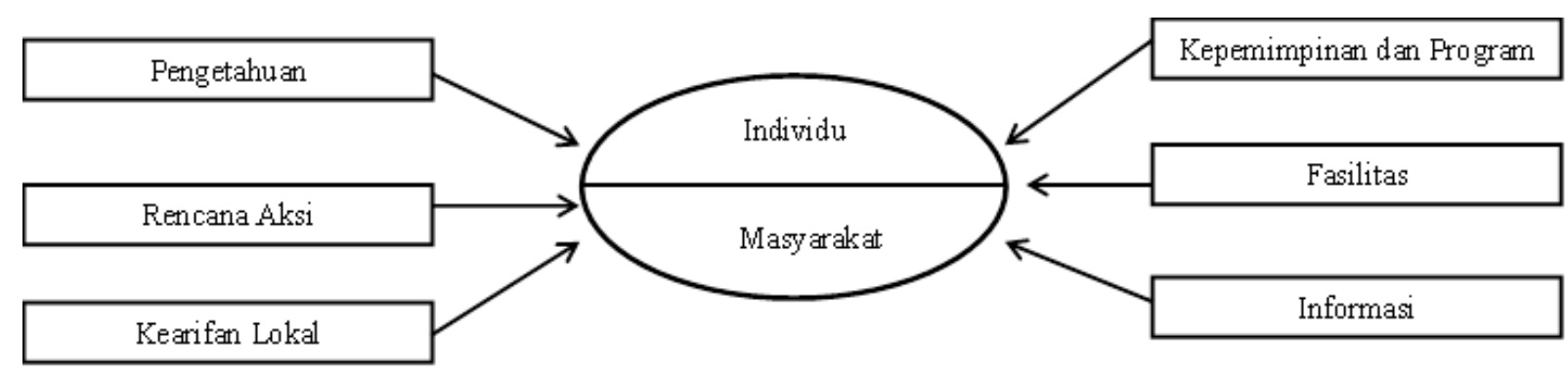

Gambar 4. Konsep Kapasitas Masyarakat

\section{METODE PELAKSANAAN}

Sosialisasi Peningkatan Kapasitas Masyarakat dalam Pengurangan Risiko Bencana dilaksanakan di Balai Desa Pujonkidul, Kecamatan Pujon, Kabupaten Malang pada hari Senin tanggal 11 November 2019. Pelaksanaan kegiatan dimulai jam 10.00 sampai jam 12.00 WIB. Sasaran kegiatan adalah aparat dan masyarakat desa. Harapannya setelah pelaksanaan kegiatan ini ditetapkannya peraturan desa mengenai pengurangan risiko bencana dan meningkatkanya pengetahuan masyarakat dalam hal kebencanaan.

Tahapan kegiatan pengabdian kepada masyarakat meliputi:

a. Survei lapangan untuk mengidentifikasi permasalahan yang dihadapi oleh masyarakat.

b. Pendekatan kualitatif deskriptif untuk mengidentifikasi kondisi eksisting masyarakat

c. Mendesain kegiatan sesuai hasil analisis

d. Menentukan sasaran kegiatan e. Pelaksanaan kegiatan berupa sosialisasi

f. Evaluasi hasil pengabdian kepada masyarakat

g. Pelaporan dan penyusunan artikel ilmiah.

\section{HASIL DAN PEMBAHASAN}

Kegiatan sosialisasi dihadiri oleh aparat desa, karang taruna dan masyarakat Desa Pujonkidul sebanyak 20 orang. Kegiatan ini diawali dengan pembagian pre test mengenai pengurangan risiko bencana, pembagian handout, sosialisasi, tanya jawab dan diakhiri dengan pembagian post test. Hasil pre test dapat dilihat pada Gambar 5. 


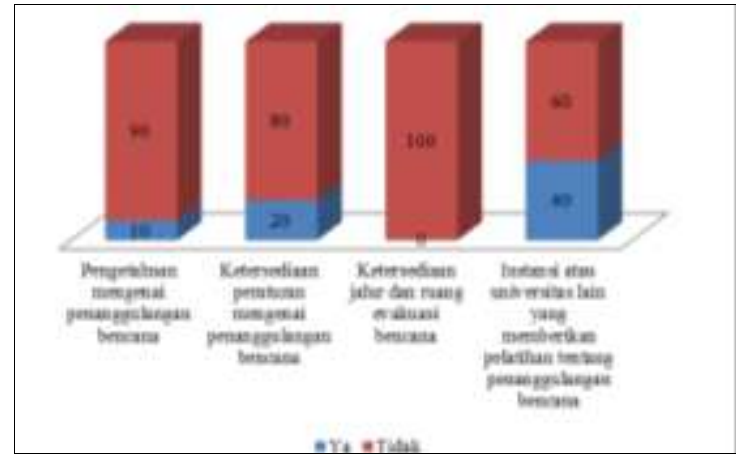

Gambar 5. Pengetahuan Awal Peserta

Pengabdian Tentang Penanggulangan Bencana Sebelum Sosialisasi

Gambar 5 hasil pre test terhadap 20 masyarakat desa menunjukkan bahwa $90 \%$ masyarakat desa belum mengerti dan paham mengenai penanggulangan bencana. Menurut Khasyir dkk, kurangnya pengetahuan masyarakat menjadikan ketidakmampuan desa dalam mengembangkan kapasitasnya (Khasyir et al, 2016).

Ketersediaan peraturan desa mengenai penanggulangan bencana $80 \%$ responden menjawan tidak tersedia. Ketersediaan jalur dan ruang evakuasi bencana, $100 \%$ responden menjawab Desa Pujonkidul belum tersedia jalur dan ruang evakuasi bencana. Adanya instansi atau universitas lain yang memberikan pelatihan tentang penggulangan bencana, $60 \%$ responden menjawab tidak ada.

Materi yang disampaikan dalam sosialisasi peraturan desa mengenai penyelenggaraan penanggulangan bencana Peraturan Kepala BNPB No. 01 Tahun 2012 tentang Pedoman Umum Desa/Kelurahan Tangguh Bencana yang berisi: (Gambar 6)

a. Dasar hukum

b. Ketentuan umum

c. Asas, prinsip dan tujuan

d. Tanggung dan wewenang

e. Hak dan kewajiban masyarakat

f. Forum pengurangan risiko bencana

g. Tim tanggap darurat bencana desa

h. Mitigasi dan peringatan dini, dan

i. Pembiayaan.

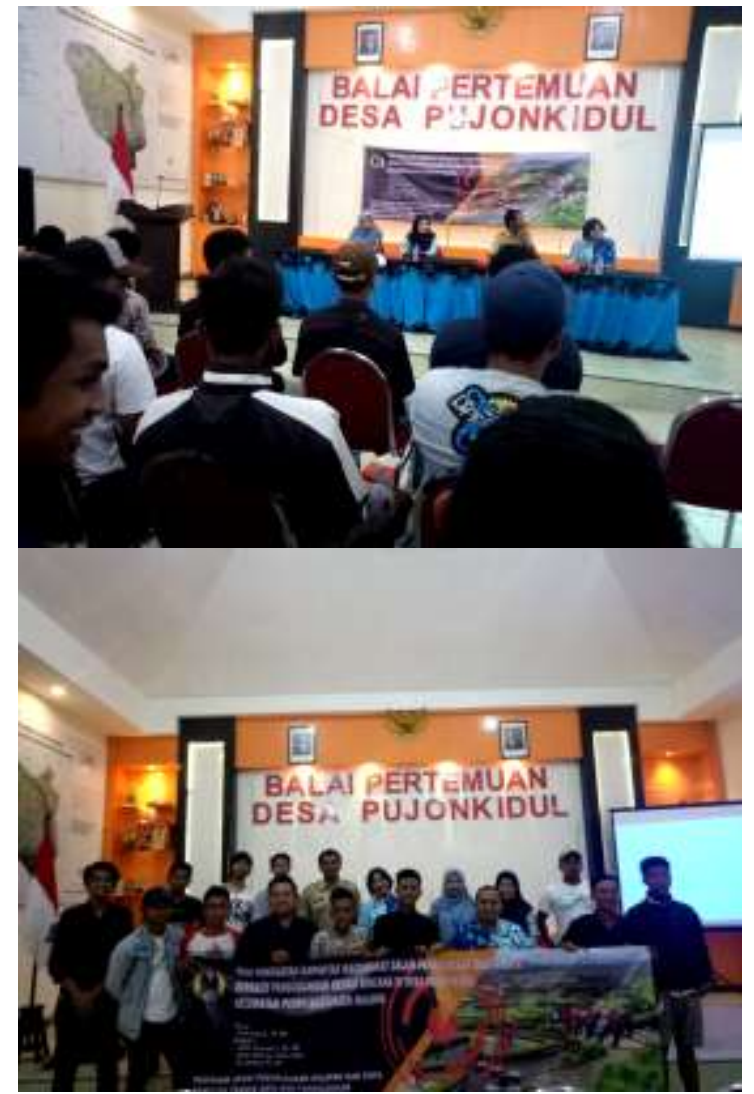

Gambar 6. Sosialisasi Naskah Peraturan

Desa

Gambar 7 hasil post test terhadap 20 masyarakat desa menunjukkan bahwa $90 \%$ masyarakat desa mengerti dan paham mengenai penanggulangan bencana. Ketersediaan peraturan desa mengenai penanggulangan bencana $50 \%$ responden menjawab tersedia. Dokumen Rencana Penanggulangan Bencana (PRB) menjadi acuan bagi desa dalam menyusun program pembangunan yang terkait dengan penanggulangan bencana desa melalui proses perencanaan pembangunan di tingkat desa (Oktari, 2018). Ketersediaan jalur dan ruang evakuasi bencana, $50 \%$ responden menjawab Desa Pujonkidul tersedia jalur dan ruang evakuasi bencana. Adanya instansi atau universitas lain yang memberikan pelatihan tentang penggulangan bencana, $100 \%$ responden menjawab tidak ada. 
semua-kecamatan-di-malang-rawan-

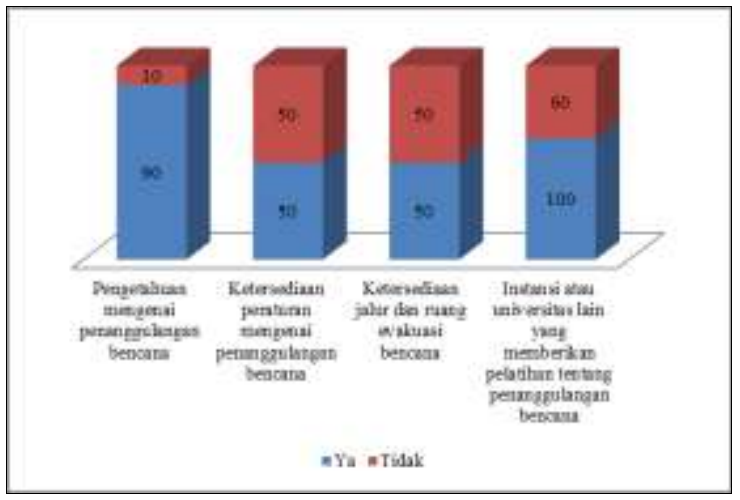

Gambar 7. Pengetahuan Awal Peserta Pengabdian Tentang Penanggulangan Bencana Setelah Sosialisasi

Pasca dilaksanakan sosialisasi penanggulangan bencana di Desa Pujonkidul diharapkan segera ditetapkan peraturan desa mengenai penyelenggaraannya sehingga dapat mendukung potensi lokal Desa Pujonkidul yaitu sebagai desa wisata.

\section{KESIMPULAN}

Kegiatan sosialisasi Peningkatan Kapasitas Masyarakat dalam pengurangan risiko bencana diikuti oleh 20 orang masyarakat Desa Pujonkidul. Pelaksanaan kegiatan dimulai dari jam 10.00 sampai jam 12.00 WIB. Kegiatan sosialisasi berisi tentang penyampaian materi mengenai penanggulangan bencana. Masyarakat desa sangat antusias dalam kegiatan ini. Diharapkan pasca kegiatan ini segera ditetapkan peraturan desa mengenai penyelanggaraan penanggulangan bencana di Desa Pujonkidul dan dapat menunjang potensi desa wisata.

\section{REFERENSI}

Ahdi, D. (2015). Perencanaan Penanggulangan Bencana Melalui Pendekatan Manajemen Risiko. ejurnal UNITRI Vol. 5 No 1. www.jurnal.unitri.ac.id diakses 13 Agustus 2019).

Al Faruq, DU. 2019. Sетиа Kecamatan di Malang Rawan Bencana. https://nusantara.medcom.id/jawatimur/peristiwa-jatim/0kpzM1EN- bencana (diakses 13 Agustus 2019).

Fadhil, B. (2013). Manajemen Kesehatan pada Penanggulangan Bencana. https://www.slideshare.net/Bambangpriy ono/manajemen-kesehatan-padapenanggulangan-bencana (diakses 19 Maret 2020).

Khasyir, M., Aji, A. \& Setyaningsih, W. (2016). Penilaian Risiko Bencana Tanah Longsor Desa Wanadri Kecamatan Bawang Kabupaten Banjarnegara. Jurnal Geo Image Vol 5 No 2 (diakses 19 Maret 2020).

Lupito, A. (2018). 100 Desa Masuk Rawan Bencana. https://radarmalang.id/100desa-masuk-rawan-bencana/ (diakses 13 Agustus 2019).

Nugraha, J., Nugraheni, F. \& Kurniawan, I. N. (2016). Model KAPASITAS MASYARAKAT Dalam Menghadapi Bencana Menggunakan Analisis Regresi Logistik Ordinal. Eksakta. https://www.neliti.com/id/publications/8 0311/model-kapasitas-masyarakatdalam-menghadapi-bencanamenggunakan-analisis-regresi (diakses 18 Maret 2020).

Oktari, R. S. (2018). Peningkatan Kapasitas Desa Tangguh Bencana. Jurnal Pengabdian kepada Masyarakat Vol. 4 No. 2. DOI:http://doi.org/ 10.22146/jpkm.29960.

https://jurnal.ugm.ac.id/jpkm/article/dow nload/29960/24152 (diakses 19 Maret 2020).

Rachmadana, S.L. (2018). Implementasi Strategi Diversifikasi Produk Untuk Mencapai Keunggulan Bersaing Pada Desa Wisata Pujonkidul. Skripsi Jurusan Manajemen Universitas Islam Negeri Maulana Malik Ibrahim (diakses 19 Maret 2020). 
